\title{
SASKATCHEWAN NIS'KU PROJECT
}

The Saskatchewan Government deserves praise for its enterprise and vision in planning the Saskatchewan Nis'ku Project to re-establish the Canada Goose in the southern part of the prairie provinces.

Conservationists have long been aware that in the process of settling the west (the changing of huge expanses of grassland plains and marsh areas) ensuing habitat changes threatened the very existence of a bird such as the Canada Goose. Now, with the development of an area ideally situated for the purpose of maintaining waterfowl, Saskatchewan should be assured of the presence of productive flocks of this attractive bird whose name in the Cree language is Nis'ku.

The section of the province chosen for the Nis'ku Project is a 2,000 acre marsh on Eyebrow Lake, just below the Summit Dam on Diefenbaker Lake. Since the formation of Diefen- baker Lake flooded valuable habitat ir a richly productive wildlife area, th choice of Eyebrow Lake, itself a con centration area for migratory birds is particularly happy.

A glance at the map will show hou it is possible to divert a controllec amount of water from the channe leading out of Diefenbaker Lake in order to make the Nis'ku Projec function adequately. Dikes and wate control structures were built by the DNR construction branch in the latter part of 1968 dividing the Eyebrow Lake area into five managemen units ranging in size from 110 to 800 acres. Each compartment is designec to allow individual water manipula tion and management practices. Addi tional compartments may be added as required by constructing new dikes Provision has already been made tc fence one compartment this spring to

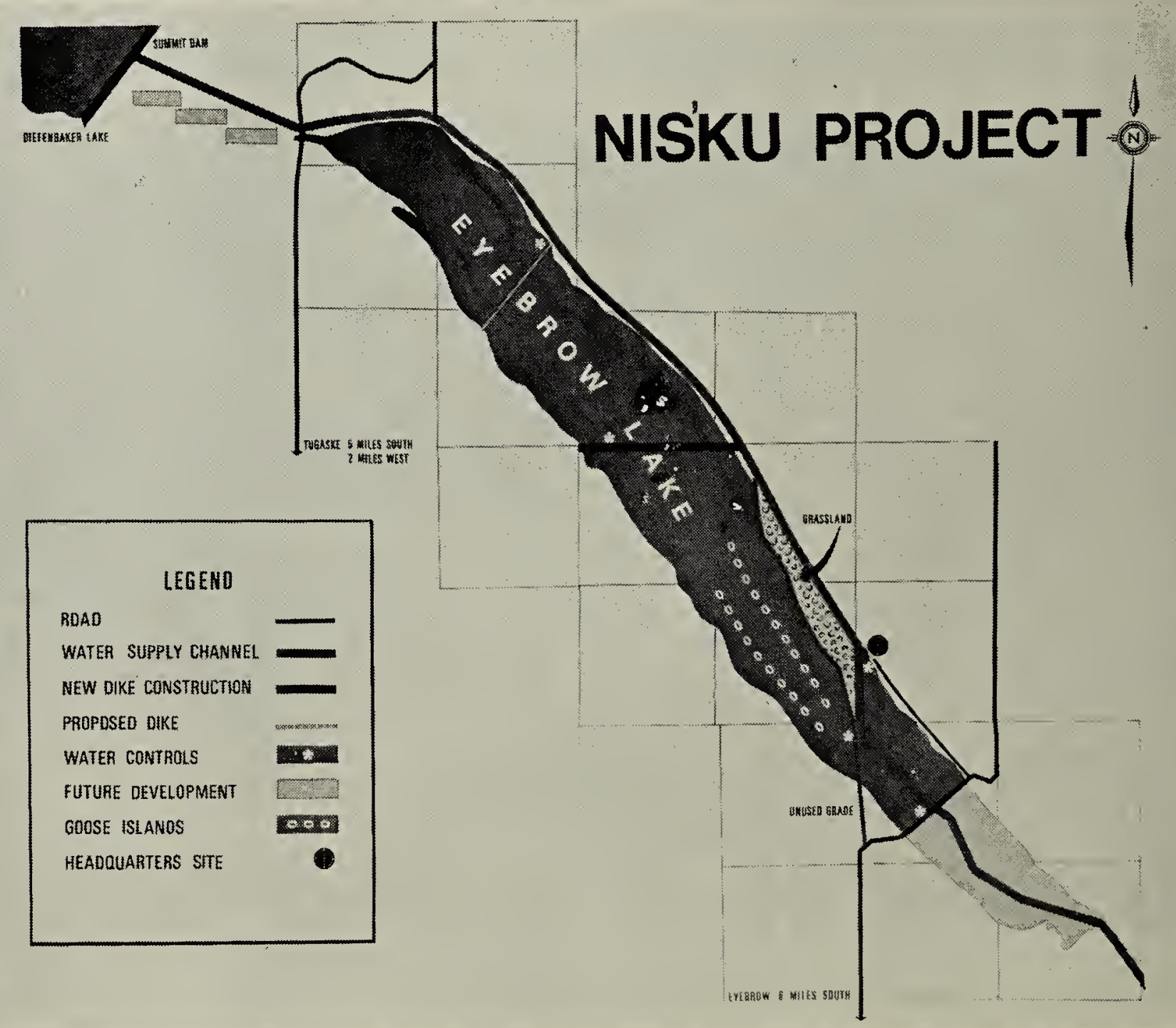




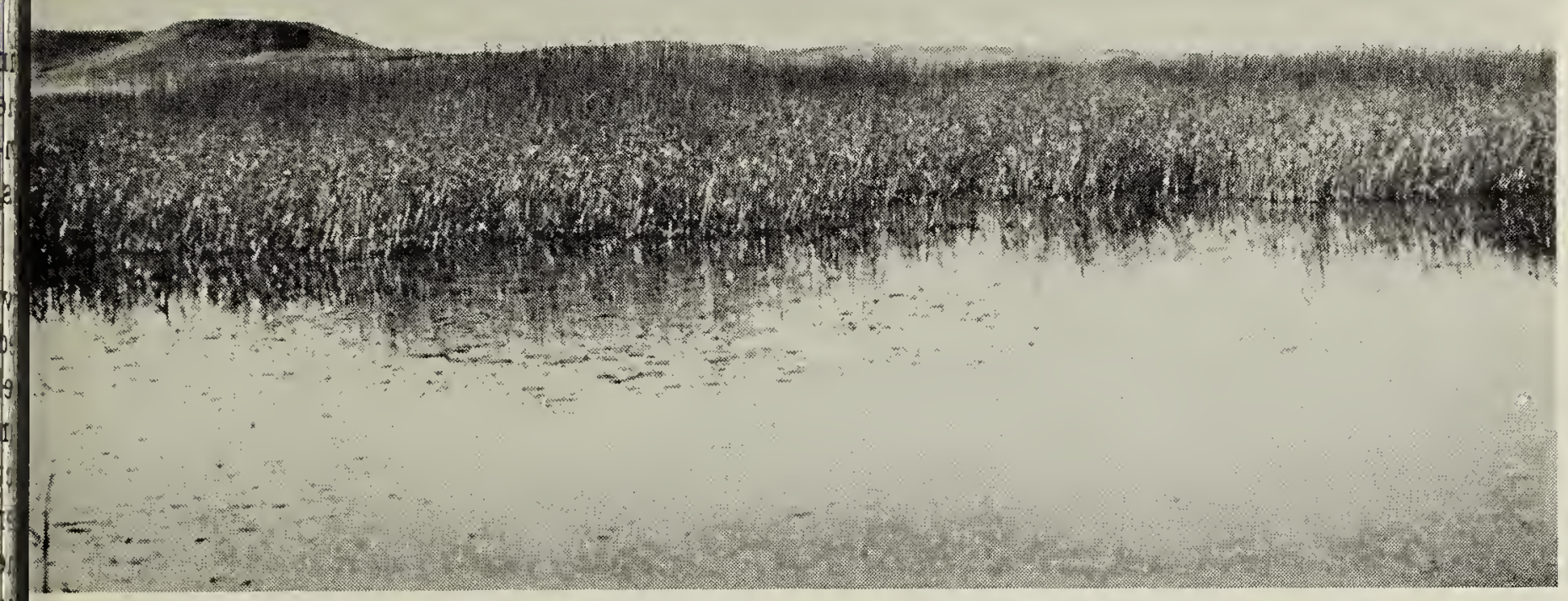

Eyebrow Lake in mid - 50's

hold the young birds which will be placed on the site in July. Twenty-one earthern islands have been constructed to form basic nesting habitat and resting areas for the wild flock. The location of these islands is clearly indicated on the map.

Through the co-operation of Fred Bard, Director of the Saskatchewan Museum of Natural History, and officials of the New Mexico Bosque de Apache National Wildlife Refuge the project commenced operations this spring.

Mr. Bard was to collect eggs when the geese already located at the Wascana Waterfowl Park laid their first clutch this season. The second clutch laid was also to be collected and incubated. The goslings will be transported to the Saskatoon Game Farm, there to await release on the Nis'ku site. A total of 500 goslings is expected to be available for the initial release. (Incidentally, the nucleus of the Wascana flock will not be affected.)

Twenty-eight adult geese have been live-trapped on their wintering ground in the New Mexico Bosque de Apache National Wildlife Refuge with the cooperation of the New Mexico Game Department. These free-flying birds have been transported to the Saskatoon Game Farm and will be wingclipped and released on site with the

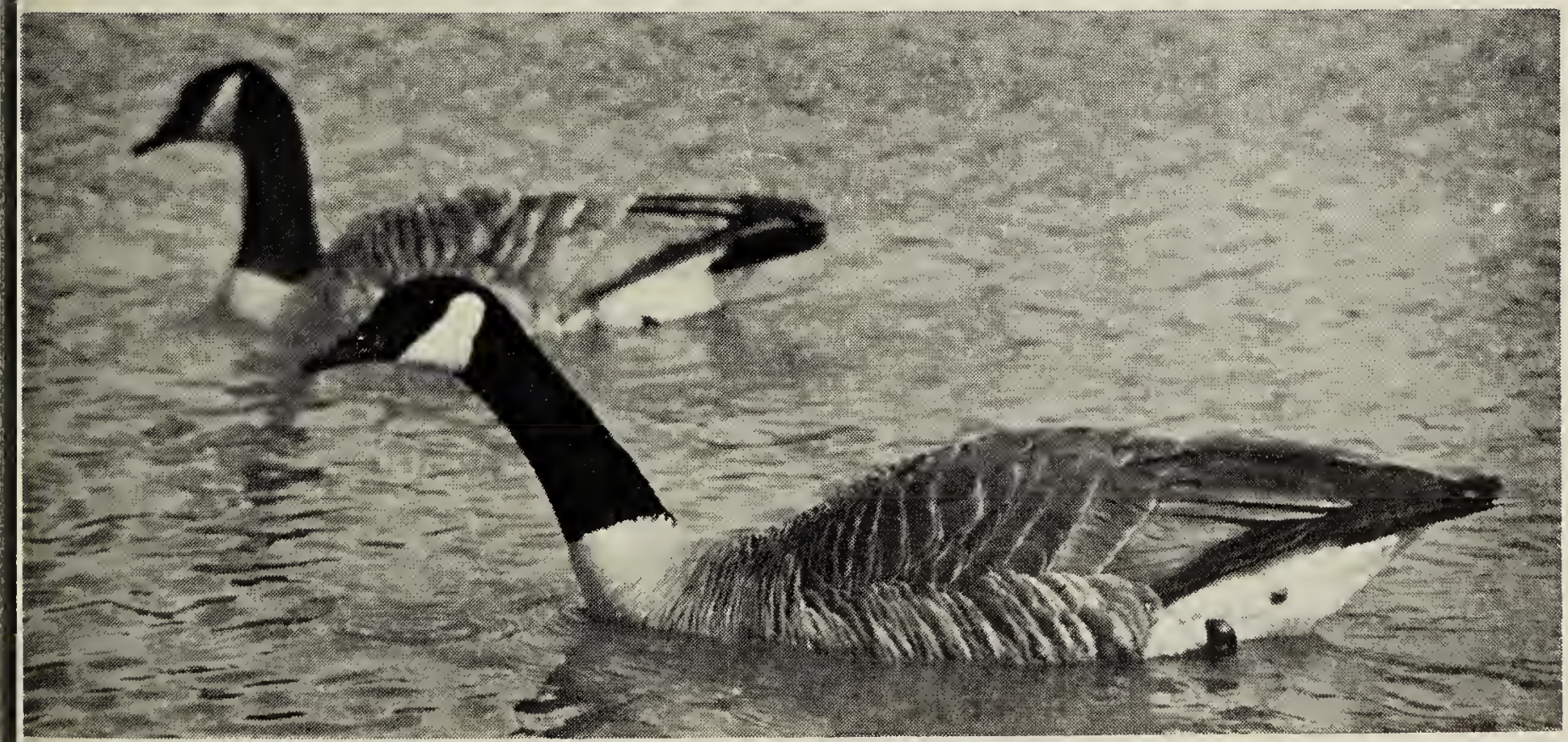

Photo by Saskatchewan Museum of Natural History Greater Canada Goose in Wascana Waterfall Park 


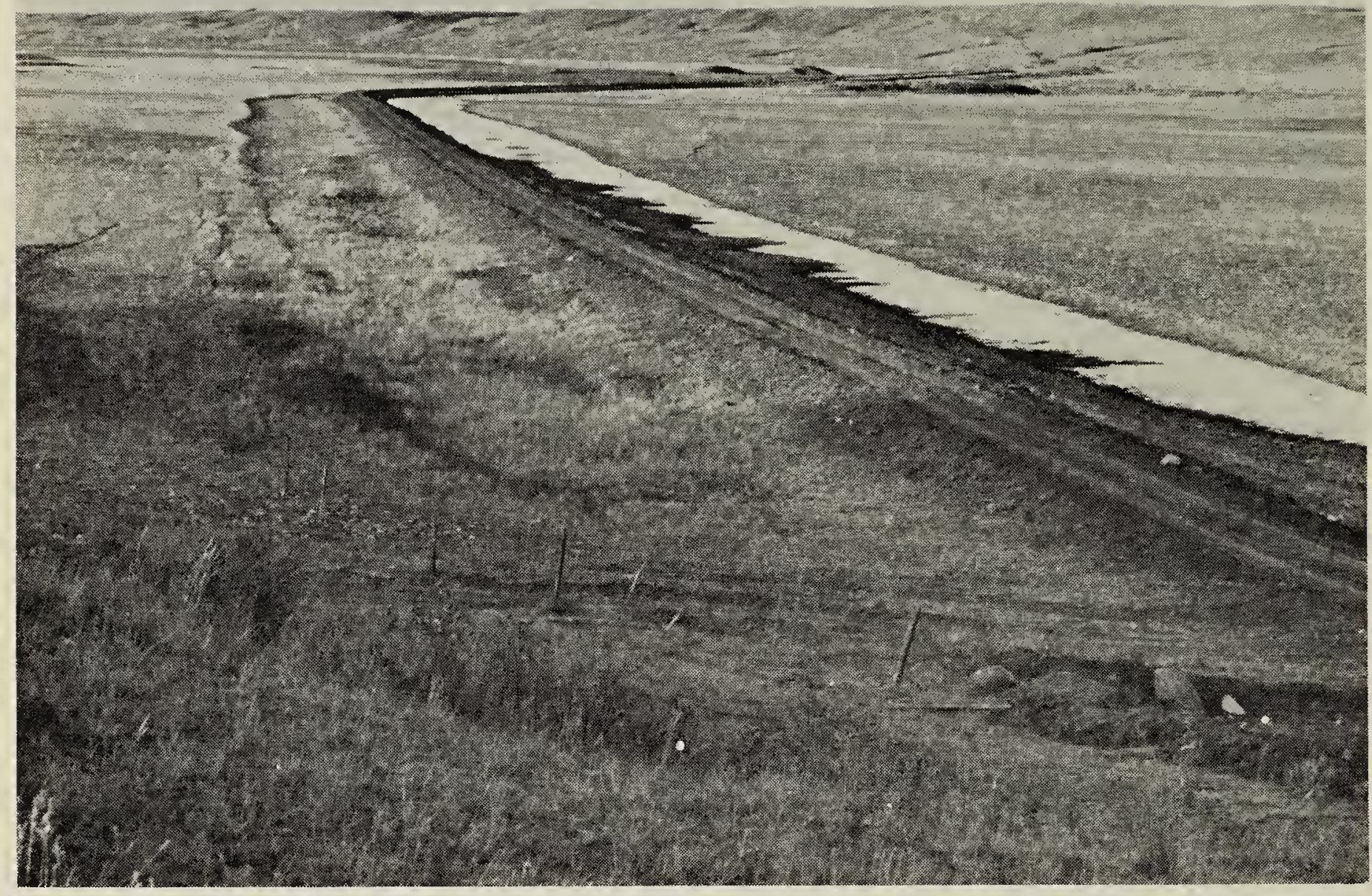

Saskatchewan Government Photo

Nis'ku Project in Qu'Appelle Valley near Eyebrow. Dike forms marsh management unit. Note nesting islands at extreme left.

younger birds. It is hoped these grown geese will, in later months, lead the goslings to the New Mexico winter migration area along a flyway which experiences light hunting pressure. All geese will be banded as they are released to aid management officials in determining the migration patterns of these birds.

By 1975 , it is hoped that a resident breeding flock as well as a wild flock of large Canada Geese will be established at Eyebrow Lake. The resident flock will form the backbone of the production unit and will number approximately 500 pairs. These will be maintained at the headquarter site. It is also hoped that by 1975 the project will have a resident manager, wintering barns, fenced brooding pens, and incubator and all other necessary rearing facilities entailed in a development of this size. It has been estimated that between five to seven thousand Canada Goose goslings will be available on a yearly basis to provide breeding stock for additional lakes and marshes across the province.

Mr. Dave Gray, DNR ecologist in charge of the Nis'ku program has this to say about the project: "The Prairie Canada Goose is an intrinsic part of Saskatchewan's heritage. With the establishment of Nis'ku, an integral portion of our human environment will be preserved ..."

The effects of the Nis'ku Project will indeed be far-reaching. Not only will this development ensure the survival of a bird which has become a symbol of conservation but it will also encourage the public generally to take a closer look at the whole problem of habitat improvement for our natural wildlife. Planning does make the difference.-Digest from D.N.R. news release. 